\title{
Dry Sliding Wear Behaviour of Talc-Reinforced UHMWPE Composite for Implant Application
}

(Kelakuan Kehausan Kering terhadap Komposit UHMWPE Diperkuat dengan Talkum untuk Aplikasi Implan)

\author{
BOON PENG CHANG*, HAZIZAN Md AKIL \& RAMDZIAH BT MD NASIR
}

\begin{abstract}
As of today, ultra-high molecular weight polyethylene (UHMWPE) is a thermoplastic material normally used as bearing components for human joint replacements. However, formation of wear debris from UHMWPE after certain service periods may cause adverse effects which remain as unresolved issues. In this study, mechanical and dry sliding wear properties of UHMWPE reinforced with different loading of talc particles were investigated. The wear test was carried out using Ducom TR-20 pin-on-disc tester at different pressure velocity $(\mathrm{pv})$ factors under dry sliding conditions. The worn surfaces and transfer films of pure UHMWPE and talc/UHMWPE composites were observed under scanning electron microscope (SEM). The experimental results showed that the microhardness increased with the increase of talc loadings in UHMWPE. The $20 \mathrm{wt}$. \% talc/UHMWPE composites showed a $17 \%$ increment in microhardness as compared with pure UHMWPE. The dry sliding wear behaviour of UHMWPE was also improved upon the reinforcement of talc. The wear rate of UHMWPE decreased after incorporation of talc particles. The coefficient of friction (COF) increased slightly under low $p v$ conditions. At high pv conditions, the COF decreased in values with increasing talc loadings. The improvement in wear behaviour may be attributed to the increase in load-carrying capacity and surface hardness of the talc/UHMWPE composites. SEM micrographs on worn surfaces showed that plastic deformation and grooving wear were dominant for UHMWPE. The plastic deformation and grooving wear were reduced upon the reinforcement of talc particles. The talc/ UHMWPE composites produced smoother and uniform transfer films as compared to pure UHMWPE.
\end{abstract}

Keywords: Coefficient of friction; composite; dry sliding wear; talc; UHMWPE

\section{ABSTRAK}

Sehingga hari ini, polietilena berat molekul ultra-tinggi (UHMWPE) adalah bahan termoplastik yang selalu digunakan sebagai peranti bearing untuk penggantian sendi manusia. Tetapi, serpihan haus yang dihasilkan daripada UHMWPE selepas tempoh perkhidmatan tertentu boleh mendatangkan kesan buruk kepada badan manusia dan ini masih merupakan satu isu yang belum diselesaikan. Dalam kajian ini, komposit UHMWPE tetulang dengan kandungan partikel talkum yang berbeza terhadap sifat-sifat mekanikal dan kehausan telah dikaji. Ujian kehausan telah dikaji dengan menggunakan penguji pin-atas-cakera Ducom TR-20 di bawah faktor tekanan dan kelajuan (pv) yang berbeza dalam keadaan gelongsoran kering. Permukaan lelasan dan filem pemindahan yang terhasil selepas ujian geseran bagi UHMWPE tulen dan komposit talkum/UHMWPE telah diperhatikan dengan menggunakan mikroskop elektron imbasan (SEM). Keputusan telah menunjukkan bahawa mikro-kekerasan UHMWPE meningkat dengan peningkatan kandungan talkum dalam komposit. Komposit 20 wt. \% talkum/UHMWPE menunjukkan peningkatan mikro-kekerasan sebanyak $17 \%$ berbanding dengan UHMWPE tulen. Sifat kehausan UHMWPE juga diperbaiki setelah diperkuat dengan partikel talkum. Kadar kehausan UHMWPE didapati berkurang dengan penambahan partikel talkum. Pekali geseran (COF) didapati meningkat sedikit dalam keadaan pv yang rendah. Manakala dalam keadaan pv tinggi, pekali geseran komposit UHMWPE menurun selepas diperkuat dengan partikel talkum. Pembaikan sifat kehausan adalah disebabkan oleh peningkatan kapasiti menahan-beban dan kekerasan permukaan komposit talkum/UHMWPE. Mikrograf SEM terhadap permukaan haus menunjukkan ubahan plastik dan alur haus adalah dominan bagi UHMWPE. Deformasi plastik dan alur haus UHMWPE didapati berkurangan selepas diperkuatkan dengan partikel talkum. Komposit talkum/UHMWPE menghasilkan filem pemindahan yang lebih licin dan seragam berbanding dengan UHMWPE tulen.

Kata kunci: Kelakuan kehausan kering; komposit; pekali geseran; talkum;UHMWPE

\section{INTRODUCTION}

UHMWPE is one of the best engineering thermoplastic that possesses high impact strength, low friction coefficient, good bio-compatibility and high chemical inertness.
It exhibits the highest wear resistance as compared to other thermoplastic (Budinski 1997) due to its long chain entanglement. It is an established material for many years which can be applied as artificial joint replacement 
components; prosthetic joints that are able to replace degraded human joints caused by severe arthritis or injuries. Despite its exceptional properties, wear problem that occurred after certain service periods still remain as the main challenge. The production of wear debris will cause adverse effects to human body system which subsequently leads to osteolysis and aseptic loosening of the implant. On that matter, it is imperative for researches in polymer tribology to reduce the wear rate of UHMWPE components in artificial joint replacements. In order to improve the tribological properties of UHMWPE, several methods have been attempted and studied by researchers. Among the methods are crosslinking with electron beam irradiation (Kurtz et al. 1999; Shen et al. 1999), heat treatment and annealing (Chiesa et al. 2004; Fouad et al.2005), particles and fiber reinforcement such as zirconium particles (Plumlee \& Schwartz 2009), wollostonite fiber (Tong et al. 2003), natural coral (Ge et al. 2009), hydroxyapatite (Fang et al. 2006), carbon fiber (Dangsheng 2005), alumina (Xiong \& Ge 2001) and zinc oxide (Chang et al. 2013).

Micro- and nano- scale fillers are well known to have the ability to enhance the mechanical properties of the polymer materials. These polymer composites possess remarkable properties as compared to unfilled polymer such as improved electrical and thermal conductivity, mechanical strength, optical properties and degree of crystallinity. Talc is an inorganic mineral composed of hydrated magnesium silicate $\left(\mathrm{Mg}_{3} \mathrm{Si}_{4} \mathrm{O}_{10}(\mathrm{OH})_{2}\right)$ with platelike structure. For decades, talc particles have been used in many applications such as paint, cosmetic, cooling powder, food colourings and pharmaceutical. Talc is widely used as reinforcement in the polyolefin industry due to its high availability, good mechanical properties, as anti-blocking agent and low in cost. Talc-reinforced plastic has become an important composite material in automotive applications such as bumpers, dashboards and interior panels. From the literature, it was reported that reinforcement of talc in polymer composites exhibits significant improvement in the mechanical properties (Qiu et al. 2000). Leong et al. (2004) studied three types of mineral fillers i.e. talc, kaolin and calcium carbonate $\left(\mathrm{CaCO}_{3}\right)$-reinforced polypropylene (PP) on the mechanical properties and interfacial interactions. They found that talc-reinforced PP exhibited higher tensile strength; modulus and better interfacial interaction as compared to kaolin and $\mathrm{CaCO}_{3}$-reinforced PP composite system. Talc has been proven to be a strong nucleating agent in promoting nucleation in polymer (Qiu et al. 2000). There are a number of studies carried out to improve the wear behaviour of UHMWPE by reinforcing it with clay minerals such as kaolin (Guofang et al. 2004) and montmorillonite (Wen et al. 2008). Surprisingly, the use of talc particles-reinforced UHMWPE composites on friction and wear behaviour has not been reported before. The non-toxicity and chemical stable formulation of talc are some of the advantages for it to become a potential candidate in implant applications.

The friction and wear behaviour of polymer composites are very complicated and affected by several factors such as size and shape of reinforcement, filler loading, type of fillers, orientation of fiber and transfer films forming. In order to investigate the influence of talc particles on tribological properties of UHMWPE, UHMWPEreinforced with different loadings of talc particles were prepared by compression moulding. The mechanical and sliding wear behaviour of talc/UHMWPE composites were studied.

\section{EXPERIMENTAL DETAILS}

\section{MATERIALS}

UHMWPE grade GUR 4120 in powdered form with an average molecular weight of $5 \times 10^{6} \mathrm{~g} / \mathrm{mol}$ and density of $0.93 \mathrm{~g} / \mathrm{cm}^{3}$ was provided by Ticona Engineering Polymer (Shanghai, China). Commercial talc powder of less than $45 \mu \mathrm{m}$ in particle size was supplied from Ipoh Ceramic Sdn. Bhd. Perak, Malaysia.

\section{COMPOSITES PREPARATION}

Composites were produced using a hot compression molding machine (GT 7014-A30C, GOTECH Inc., Taiwan) with compression pressure of 1000 psi ( 6.90 MPa). Different loadings of talc were mixed homogeneously with UHMWPE using a dry mechanical ball mill. Mixing process took $4 \mathrm{~h}$ to complete: $2 \mathrm{~h}$ each for both clockwise and anti-clockwise directions with a rotation speed of $30 \mathrm{~Hz}$. After mixing, the compound was pre-heated at a temperature of $160^{\circ} \mathrm{C}$ for $10 \mathrm{~min}$ and hot pressed for $7 \mathrm{~min}$. Composite sheet was obtained after cool pressing at $15^{\circ} \mathrm{C}$ for $5 \mathrm{~min}$. Composite sheets were then cut into appropriate dimensions for further testing.

\section{MECHANICAL PROPERTIES}

The surface hardness test was performed using Shimadzu Vickers microhardness tester type-M. The microhardness number $\left(H_{m v}\right)$ was obtained from (1):

$$
H_{m v}=1854.4 \times \frac{P}{d^{2}}
$$

where $P$ is the test load on the diamond indentor $(\mathrm{g})$, $d$ is the diagonal length measurement of the pyramidal indentation on the sample surface $(\mu \mathrm{m})$. The test load for the indentation was $50 \mathrm{~g}$ with the dwell time of $10 \mathrm{~s}$. A total of five measurements at different locations were taken on each sample and the mean and standard deviation were calculated.

\section{SLIDING WEAR AND FRICTION TEST}

The study of the sliding wear and friction behaviour was performed using Ducom TR-20 pin-on-disc tribometer. Pin-shaped specimens, $30 \mathrm{~mm}$ long, $8.5 \mathrm{~mm}$ thick and 8.5 $\mathrm{mm}$ wide were cut from the compress moulded sheet. The contact area was $8.5 \mathrm{~mm} \times 8.5 \mathrm{~mm}$. The specimens were 
slided on an abrasive paper grit $1200\left(\mathrm{R}_{\mathrm{a}} \sim 5 \mu \mathrm{m}\right)$ pasted on the stainless steel disc as counterface. All the samples were measured before and after the test on a Shimadzu (AUW220D) digital electronic balancer with a decimal place of $\pm 0.01 \mathrm{mg}$ accuracy to obtain the weight loss of each sample. The weight loss was then converted to volume loss by dividing it with specific density. The wear rate, $W$ was calculated according to Archard's wear (2) (Archard 1953) as shown below:

$$
W=\frac{V}{F D}
$$

where, $V$ is the volume loss, $F$ is the applied load and $D$ is the sliding distance. The test was carried out in dry condition for $600 \mathrm{~s}$ at various pressure velocity (pv) factors. The details of the test conditions are shown in Table 1. The arising friction forces and coefficient of friction (COF) of the samples during the wear test was recorded in Winducom 2010 software. The average COF was calculated from the data obtained. The wear tests were performed twice for every sample and the average value is reported. The results of the sliding wear and COF were plotted against the weight fraction of talc's loadings under different pv factors.

\section{WORN SURFACES AND TRANSFER FILMS ANALYSIS}

The worn surfaces and transfer films produced after wear test of the composites were observed under the Hitachi TM-3000 Tabletop Scanning Electron Microscope (SEM).
Before scanning, all of the worn surfaces and transfer films of the composites were coated with gold/palladium (Au$\mathrm{Pd}$ ) layer by using a vacuum sputter chamber.

\section{RESULTS AND DISCUSSION}

\section{EFFECT OF TALC ON MECHANICAL PROPERTY OF UHMWPE}

Figure 1 shows the microhardness of the talc/UHMWPE composites as a function of talc loadings. In general, it can be seen that the microhardness value increased with the addition of talc particles in UHMWPE. The microhardness increased about $17 \%$ at $20 \mathrm{wt}$. \% talc loadings as compared to pure UHMWPE. The increase in hardness of the talc/UHMWPE composites is due to the mechanical strengthening effect of rigidity of talc particles in UHMWPE matrix. Upon the load indentation, the talc particles and UHMWPE matrix are pressed together, with one touching another and causing resistance. Thus the contact surface can withstand higher load upon force exertion although only physical interlocking between filler and matrix exist. In addition, the presence of hydroxyl groups (OH) in the chemical structure of talc may act as dentate in the polymer matrix. This $\mathrm{OH}$ groups from talc particles can interact with polymer molecules and restrict the plastic deformation of the UHMWPE matrix phase during the indentation. Hence, surface hardness of the composites increased after the addition of talc particles. However, the hardness did not increase proportionally to the talc's loading. This may be due to poor dispersion of the talc particles in the UHMWPE matrix.

TABLE 1. The test conditions and pv factors of sliding wear behaviour of UHMWPE composites

\begin{tabular}{cccccc}
\hline & $\begin{array}{c}\text { Applied load } \\
(\mathrm{N})\end{array}$ & $\begin{array}{c}\text { Contact pressure } \\
\left(\mathrm{N} / \mathrm{mm}^{2}\right)\end{array}$ & $\begin{array}{c}\text { Rotational speed } \\
(\mathrm{RPM})\end{array}$ & $\begin{array}{c}\text { Sliding } \\
\text { velocity }(\mathrm{m} / \mathrm{s})\end{array}$ & $\begin{array}{c}\mathrm{pv} \text { factor } \\
(\mathrm{MPa} \cdot \mathrm{m} / \mathrm{s})\end{array}$ \\
\hline 1 & 20 & 0.2768 & 100 & 0.2094 & 0.06 \\
2 & 30 & 0.4152 & 100 & 0.2094 & 0.09 \\
3 & 30 & 0.4152 & 200 & 0.4189 & 0.17 \\
4 & 30 & 0.4152 & 400 & 0.8378 & 0.35 \\
\hline
\end{tabular}

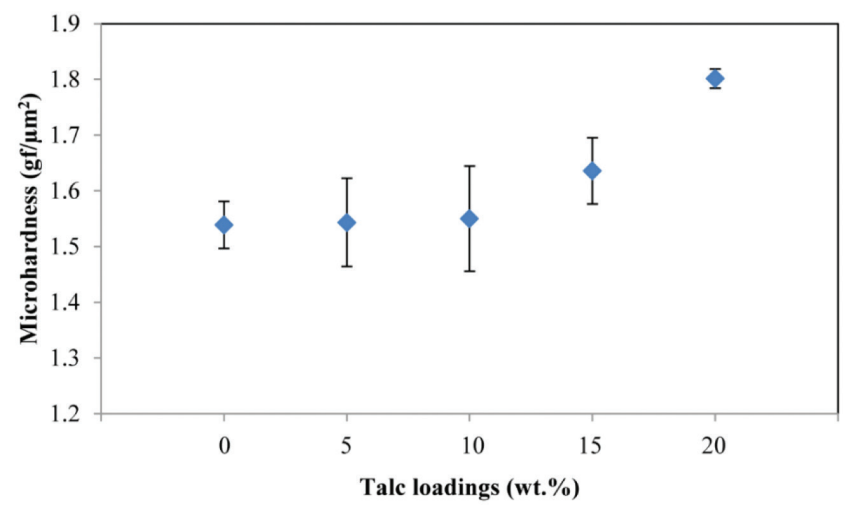

FIGURE 1. The microhardness of UHMWPE composites as a function of different talc's loadings 


\section{EFFECT OF TALC ON DRY SLIDING WEAR} BEHAVIOUR OF UHMWPE

The wear rate and coefficient of friction (COF) of pure UHMWPE and UHMWPE composites as a function of talc loadings at various pv conditions are shown in Figure 2. In general, it can be seen that the wear rate of UHMWPE decreased with increasing talc loadings. The wear rate of the pure UHMWPE was reduced from 1.4 to $1.0 \times 10^{-3}$ $\mathrm{mm}^{3} / \mathrm{Nm}$ after addition of $20 \mathrm{wt} . \%$ talc at $0.06 \mathrm{MPa} \cdot \mathrm{m} / \mathrm{s}$ pv factor (Figure 2(a)). It shows about $29 \%$ of reduction in wear rate after addition of $20 \mathrm{wt} . \%$ talc in UHMWPE as compared with pure UHMWPE. For the pv factors of $0.09 \mathrm{MPa} \cdot \mathrm{m} / \mathrm{s}$, the lowest wear rate was observed at 15 wt. \% talc/UHMWPE composite with the reduction of $40 \%$ (Figure 2(b)). At 0.17 and $0.35 \mathrm{MPa} \cdot \mathrm{m} / \mathrm{s} \mathrm{pv}$ factors, the results shown that the wear rate were reduced approximately $17 \%$ and $41 \%$, respectively, for $20 \mathrm{wt}$. \% talc/UHMWPE as compared to pure UHMWPE (Figure 2(c), 2(d)). This indicates that talc has the ability in increasing the load-carrying capacity of the composites and leads to reduction in wear rate. Load-carrying capacity is defined as the ability of sample contacting surface to withstand the action of loaded and tangential shear stress exerted from the sliding counterface. During the sliding wear test, the samples were subjected to micro-cutting and micro-ploughing from the sliding counterface asperities. This will subsequently cause the loss of surface materials from the main body of the sample. Increase in surface mechanical properties after the reinforcement of talc increased the wear resistance of the UHMWPE. The presence of talc in the composite protects the soft polymer matrix from easy removal from the bulk body and reduces the stress exerted by the sliding counterface. Therefore, the wear behaviour of UHMWPE was improved.

The COF of the UHMWPE composites as function of talc loadings at various pv conditions are also shown in Figure 2. Under low pv conditions, the increasing trend of COF was observed after the addition of talc into UHMWPE (Figure 2(a) and 2(b)). This can be attributed to the presence of talc's particles in the counterface forming three-body wear. The talc's particles in UHMWPE will also cause increase in the frictional contact due to the abrasion between the talc filler and counterface under low pv conditions. Therefore, the COF was higher for talc/UHMWPE composites as compared to pure UHMWPE. However, under high pv conditions, the COF of the samples were decreased in return. The COF showed almost constant values for both pure UHMWPE and talc/UHMWPE composites at $0.17 \mathrm{MPa} \cdot \mathrm{m} / \mathrm{s} \mathrm{pv}$ factors (Figure 2(c)). The decrease of COF after addition of talc in UHMWPE was observed for $0.35 \mathrm{MPa} \cdot \mathrm{m} / \mathrm{s}$ pv factors (Figure 2(d)). The 20 wt. \% talc/UHMWPE composites exhibited the lowest COF as compared to pure UHMWPE and other talc/ UHMWPE composites. The uniform transfer films formed by talc/UHMWPE composites on the counterface under high pv conditions were the main reason for the low COF as compared to pure UHMWPE. The transfer films grow thicker on higher $\mathrm{pv}$ conditions as compared to low pv conditions. This thick and uniform transfer films will cushion the counterface asperities. Hence frictional
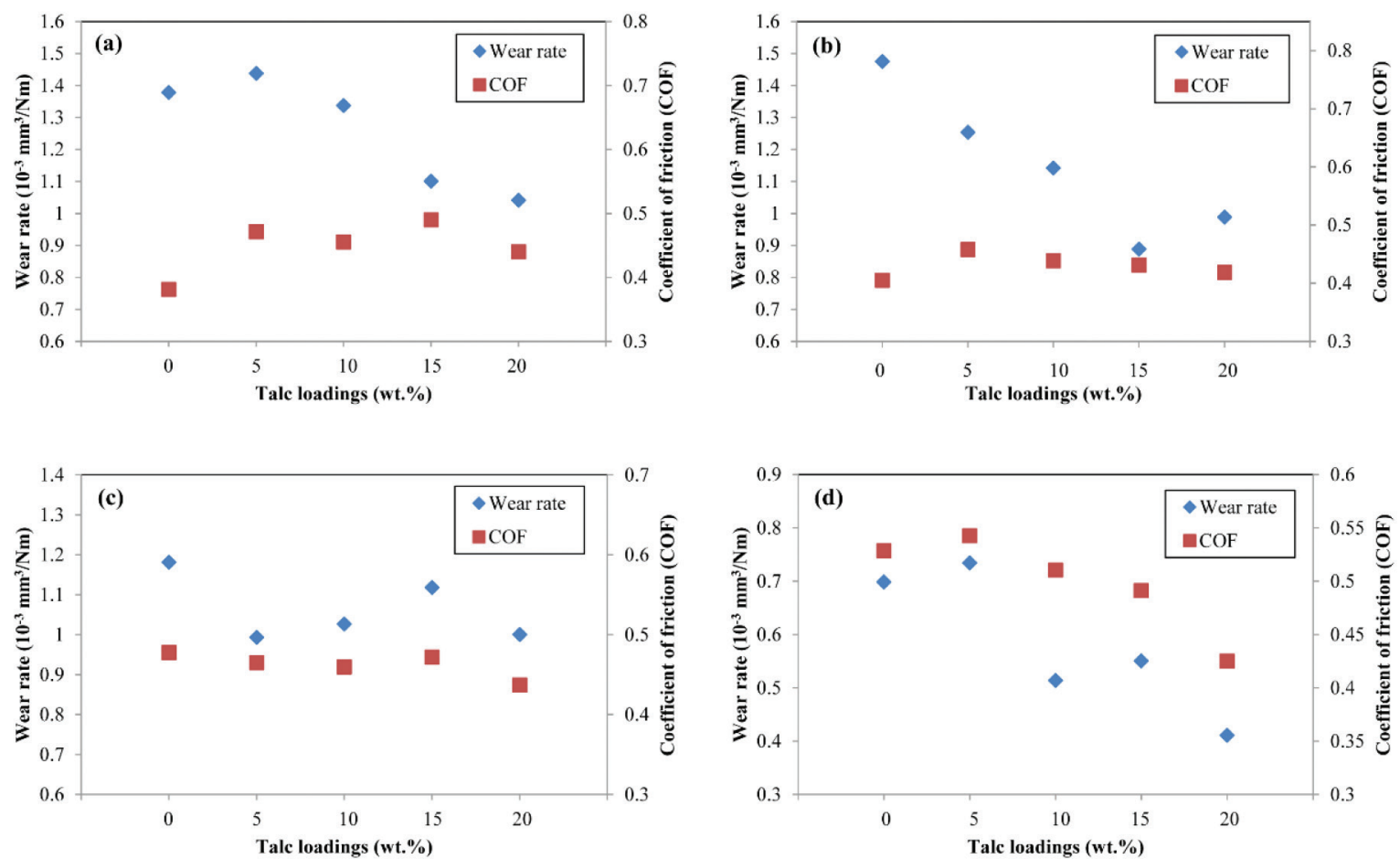

FIGURE 2. The wear rate and COF of UHMWPE and its composites at pv factors of

(a) 0.06 (b) 0.09 (c) 0.17 and (d) $0.35 \mathrm{MPa} \cdot \mathrm{m} / \mathrm{s}$ 
contact is reduced, leading to lower wear rate. The transfer film formation on the wear behaviour of UHMWPE composites are discussed in the following section.

\section{SCANNING ELECTRON MICROSCOPY ON WORN SURFACES AND TRANSFER FILMS}

Figure 3 shows the SEM micrographs of the worn surfaces of pure UHMWPE and talc/UHMWPE composites after the wear test. It can be seen that the wear grooves and furrow marks caused by the micro-cutting and micro-ploughing of the counterface asperities were dominant on the worn surfaces. For pure UHMWPE, deep wear grooves and rough surfaces were observed (Figure 3(a) and 3(c)). The severity of wear grooves on the worn surface of UHMWPE was reduced with the reinforcement of talc. Smoother worn surfaces were observed for 20 wt. \% talc/UHMWPE as compared with pure UHMWPE (Figure 3(b) and 3(d)). The surface plastic deformation reduced after the reinforcement of talc particles. This may be attributed to the increase in shear strength of the UHMWPE composites. The cutting and shearing of the counterface asperities during sliding test will cause plastic deformation and wear grooves to appear on the soft polymer surface. The incorporation of hard filler in a soft polymer matrix would allow the composite to withstand higher shear stress in comparison to pure UHMWPE. Talc particles act as a medium to support part of the shear stress and thus preventing the surface material being easily removed from the UHMWPE bulk body. Therefore, higher wear resistance was observed on the talc/UHMWPE composite surfaces compared to pure UHMWPE. In addition, the wear resistance of the polymer composites can be enhanced by improving their mechanical properties such as surface hardness (Zhang et al. 2004).
From the results obtained, the increase in microhardness of the talc/UHMWPE composites resulted in the decrease of the wear rate. The $20 \mathrm{wt}$. \% talc/UHMWPE possesses highest microhardness value and lowest wear rate. This is similar to the finding of natural coral reinforced-UHMWPE composites found by Ge et al. (2009). The increase in surface hardness of UHMWPE composites will decrease the surface plastic contact area in contact with the counterface asperities. Therefore, the wear rates of the talc/UHMWPE composites were decreased. However, the wear behaviour of polymer composites involves a complex process which does not solely depend on material behaviour, but is also dependent on other external factors such as contact temperature, pressure, sliding velocity and transfer films formation.

Currently, close attention is focused on the transfer film formation on the counterface after the wear test. The quality of the transfer films plays a significant role in the wear behaviour of polymer composites. It was confirmed that uniform transfer films produced by the particulate filler filled polymer composites will reduce wear rate of the pure polymer (Bahadur \& Sunkara 2005). The transfer films for pure UHMWPE, 10 and $20 \mathrm{wt}$. \% of talc/UHMWPE composites under $0.35 \mathrm{MPa} \cdot \mathrm{m} / \mathrm{s}$ pv factor were shown in Figure 4 . It can be seen that the pure UHMWPE produced rough and non-uniform transfer films on the counterface (Figure 4(a)). The transfer film became smoother and relatively uniform after the reinforcement of talc particles as compared to pure UHMWPE (Figure 4(b) and 4(c)). This indicates that talc-reinforced UHMWPE composites will form different transfer films as compared with pure UHMWPE. This may be due to the heterogeneous composition of the composites that leads to mechanical cohesive interaction. The uniform coverage of the transfer film produced would cushion


FIGURE 3. SEM micrographs on the worn surfaces of the pure UHMWPE ((a),(c)) and $20 \mathrm{wt}$. \% talc/UHMWPE composites ((b),(d)) at pv factors of 0.09 and $0.35 \mathrm{MPa} \cdot \mathrm{m} / \mathrm{s}$, respectively 


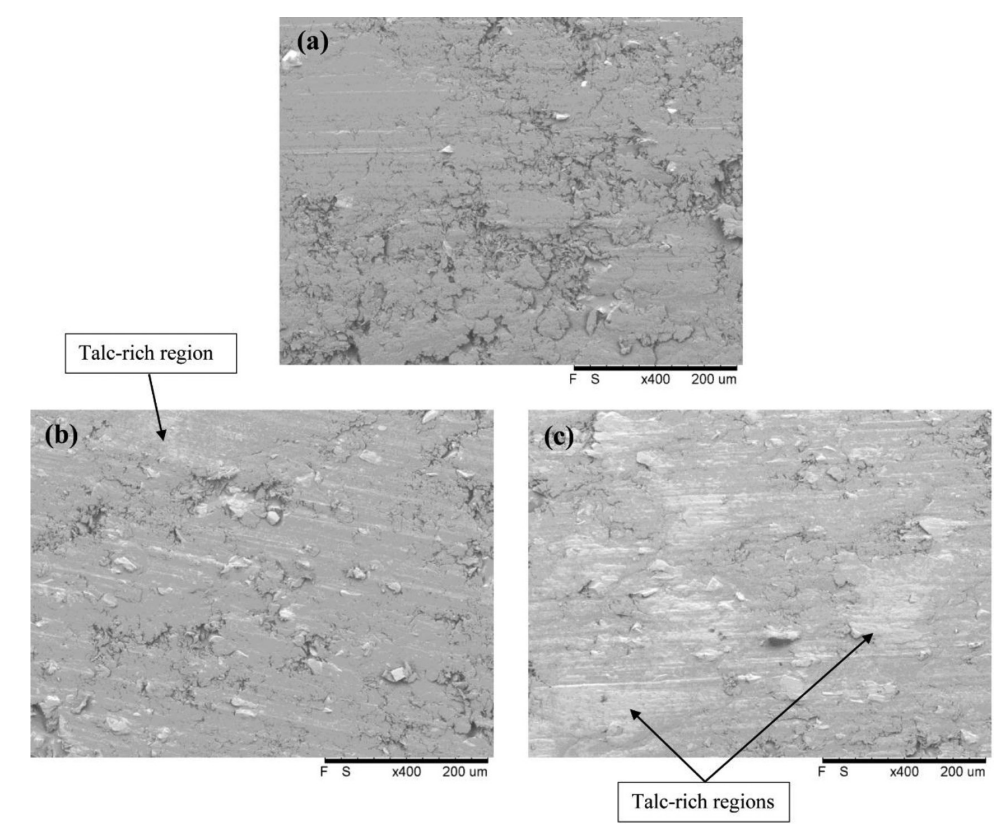

FIGURE 4. SEM micrographs of the transfer films of (a) UHMWPE, (b) $10 \mathrm{wt}$. \% talc/UHMWPE and (c) $20 \mathrm{wt} . \%$ talc/UHMWPE composites under pv factor of $0.35 \mathrm{MPa} \cdot \mathrm{m} / \mathrm{s}$

the composite from further contact with the counterface asperities and lead to reduction in wear rate. The white portions are talc-rich regions. The transfer film produced with the presence of talc particles are believed to help in improving the wear properties of UHMWPE.

\section{CONCLUSION}

The reinforcement of talc particles into UHMWPE matrix significantly improved the sliding wear behaviour of UHMWPE. The microhardness of UHMWPE increased with increasing talc loadings. Increasing surface hardness has a positive effect on wear behaviour of UHMWPE. The $20 \mathrm{wt}$. $\%$ talc/UHMWPE composite showed the lowest wear rate as compared with pure UHMWPE. The COF was increased with the addition of talc particles due to the formation of three-body wear under low pv conditions. Under high pv conditions, the COF decreased with the addition of talc's. The 20 wt. \% talc/UHMWPE composite exhibited lowest COF as compared with other talc/UHMWPE and pure UHMWPE. SEM micrographs on worn surfaces showed that plastic deformation and grooving wear were dominant for UHMWPE. The worn surface showed reduced wear severity upon reinforcement of talc particles. The talc/UHMWPE composites produced smoother and uniform transfer films as compared to pure UHMWPE. From the results obtained, talc-reinforced UHMWPE composites are capable to be implemented in joint implant applications of which wear and friction issues can be resolved.

\section{ACKNOWLEDGEMENTS}

The authors gratefully acknowledge the Universiti Sains Malaysia Fundamental Research Grant Scheme (FRGS) and Polymer Composites Research Cluster Fund for the funding of this research. The grant numbers are 203/ PBAHAN/6071242 and 1001/PKT/8640013. The first author would also like to thank Universiti Sains Malaysia (USM) fellowship program for the financial support.

\section{REFERENCES}

Archard, J.F. 1953. Contact and Rubbing of Flat Surfaces. Journal of Applied Physics 24(8): 981-988.

Bahadur, S.\& Sunkara, C. 2005. Effect of transfer film structure, composition and bonding on the tribological behavior of polyphenylene sulfide filled with nano particles of $\mathrm{TiO}_{2}, \mathrm{ZnO}$, $\mathrm{CuO}$ and SiC. Wear 285(9): 1411-1421.

Budinski, K.G. 1997. Resistance to particle abrasion of selected plastics. Wear 203-204: 302-309.

Chang, B.P., Akil, H. Md. \& Nasir, R. Bt. Md. 2013. Comparative study of micro- and nano-ZnO reinforced UHMWPE composites under dry sliding wear. Wear 297(1-2): 11201127.

Chiesa, R., Moscatelli, M., Giordano, C., Siccardi, F. \& Cigada, A. 2004. Influence of heat treatment on structural, mechanical and wear properties of crosslinked UHMWPE. Journal of Applied Biomaterials \& Biomechanic 2(1): 20-28.

Dangsheng, X. 2005. Friction and wear properties of UHMWPE composites reinforced with carbon fiber. Materials Letters 59(2-3): 175-179.

Fang, L., Leng, Y. \& Gao, P. 2006. Processing and mechanical properties of HA/UHMWPE nanocomposites. Biomaterials 27(20): 3701-3707.

Fouad, H., Mourad, A.H.I. \& Barton, D.C. 2005. Effect of preheat treatment on the static and dynamic thermo-mechanical properties of ultra-high molecular weight polyethylene. Polymer Testing 24(5): 549-556.

Ge, S., Wang, S. \& Huang, X. 2009. Increasing the wear resistance of UHMWPE acetabular cups by adding natural biocompatible particles. Wear 267(5-8): 770-776. 
Guofang, G.,Huayong, Y. \& Xin, F. 2004. Tribological properties of kaolin filled UHMWPE composites in unlubricated sliding. Wear 256(1-2): 88-94.

Kurtz, S.M., Muratoglu, O.K., Evans, M. \& Edidin, A.A. 1999. Advances in the processing, sterilization, and crosslinking of ultra-high molecular weight polyethylene for total joint arthroplasty. Biomaterials 20(18): 1659-1688.

Leong, Y.W., Abu Bakar, M.B., Ishak, Z.A.M., Ariffin, A. \& Pukanszky, B. 2004. Comparison of the mechanical properties and interfacial interactions between talc, kaolin, and calcium carbonate filled polypropylene composites. Journal of Applied Polymer Science 91(5): 3315-3326.

Plumlee, K. \& Schwartz, C.J. 2009. Improved wear resistance of orthopaedic UHMWPE by reinforcement with zirconium particles. Wear 267(5-8): 710-717.

Qiu, W., Mai, K. \& Zeng, H. 2000. Effect of silane-grafted polypropylene on the mechanical properties and crystallization behavior of talc/polypropylene composites. Journal of Applied Polymer Science 77(13): 2974-2977.

Shen, F.W., Lu, B., Campbell, P. \& Salovey, R. 1999. Development of an extremely wear-resistant ultra high molecular weight polythylene for total hip replacements. Journal of Orthopaedic Research 17(2): 157-167.

Tong, J., Ma, Y. \& Jiang, M. 2003. Effects of the wollastonite fiber modification on the sliding wear behavior of the UHMWPE composites. Wear 255(1-6): 734-741.

Wen, J., Yin, P. \& Zhen, M. 2008. Friction and wear properties of UHMWPE/nano-MMT composites under oilfield sewage condition. Materials Letters 62(25): 4161-4163.

Xiong, D. \& Ge, S. 2001. Friction and wear properties of UHMWPE/A12O3 ceramic under different lubricating conditions. Wear 250(1-12): 242-245.
Zhang, Z., Breidt, C., Chang, L. \& Friedrich, K. 2004. Wear of PEEK composites related to their mechanical performances. Tribology International 37(3): 271-277.

Boon Peng Chang* \& Hazizan Md Akil

Engineering Campus, Universiti Sains Malaysia

Nibong Tebal, 14300 Penang

Malaysia

Boon Peng Chang*

School of Engineering, Science \& Technology

KDU College (PG) Sdn Bhd

32, Jalan Anson, Georgetown

10400 Penang

Malaysia

Ramdziah bt Md Nasir

Cluster of Polymer Composite (CPC)

Science and Engineering Research Centre (SERC)

Engineering Campus

Universiti Sains Malaysia

Nibong Tebal, 14300 Penang

Malaysia

*Corresponding author; email: cbpchang@gmail.com

Received: 15 January 2014

Accepted: 15 November 2014 